\title{
Ultrasonography for noninvasive and real- time evaluation of peri-implant soft and hard tissue: a case series
}

\author{
Miriam Thöne-Mühling ${ }^{1}$, Oliver D. Kripfgans ${ }^{2}$ and Reiner Mengel ${ }^{1 *}$ (D)
}

\begin{abstract}
Background: The diagnosis of soft and hard tissue at dental implants will be challenging in the future, as high prevalence of mucositis and peri-implantitis were described in the population. Ultrasonography is a promising noninvasive, inexpensive, painless, and radiation-free method for imaging hard and soft tissue at implants, especially an ultrasound device with a 25-MHz probe demonstrating a high correlation between ultrasound, clinical, and radiological measurements.
\end{abstract}

Case presentation: The following case series demonstrates the use of ultrasonography with high spatial resolution probe in patients with dental implants affected by soft tissue recession and/or crestal bone loss.

Conclusion: These ultrasound images can provide valuable additional information for the assessment of periimplant soft and hard tissue.

Keywords: Ultrasonography, Peri-implant diagnostics, Peri-implantitis, Bone loss, Soft tissue diagnostics

\section{Background}

The diagnosis of soft and hard tissue at dental implants will be challenging in the future, as high prevalence of mucositis and peri-implantitis were described in the population $[18,45]$. More than $40 \%$ of all implants exhibit peri-implant diseases, and almost one in five implants develop increased bone loss at least once after a loading period of 3.4 to 11 years [17]. Patients with periodontal disease in particular experience increased inflammation and bone loss at implants [12, 19].

The two-dimensional intraoral radiograph is the current gold standard in the measurement of the periimplant bone loss $[46,51]$. However, radiographs only show the mesial and distal bone level; the buccal and oral bone is not visible due to the overlay of the implant. Since buccal bone at implants has shown increased bone

\footnotetext{
* Correspondence: mengel@med.uni-marburg.de

'Department of Prosthetic Dentistry, School of Dental Medicine, Philipps-University Marburg, Georg-Voigt Str. 3, 35039 Marburg/Lahn, Germany

Full list of author information is available at the end of the article
}

loss in long-term clinical studies, cone-beam computed tomography $(\mathrm{CBCT})$ and computed tomography (CT) are increasingly used as three-dimensional radiographic imaging procedures $[13,14,23,32,33,49]$. Despite the advantages of three-dimensional imaging, it remains to be noted that bony dehiscence and fenestration on implants cannot be adequately assessed [22, 54]. This is due to the low resolution limit of the image, which does not reliably represent buccal bone in the anterior maxilla, which is usually very thin and less than $1 \mathrm{~mm}$ thick $[6,21,52]$. Another disadvantage of three-dimensional images is the susceptibility to artifacts at the transition from metal to bone and soft tissue. This leads to erasure artifacts in imaging, particularly in the diagnostics of titanium implants and their metallic abutments [20, 43, 47]. In terms of radiological exposure, CBCTs generally show reduced radiation exposure compared to CTs [2830, 42]; however, their radiation exposure is 3 to 40 times higher than that of a two-dimensional panoramic image [30]. Due to the higher radiation exposure, the use of a three-dimensional radiological image is

\section{Springer Open}

(- The Author(s). 2021 Open Access This article is licensed under a Creative Commons Attribution 4.0 International License, which permits use, sharing, adaptation, distribution and reproduction in any medium or format, as long as you give appropriate credit to the original author(s) and the source, provide a link to the Creative Commons licence, and indicate if changes were made. The images or other third party material in this article are included in the article's Creative Commons licence, unless indicated otherwise in a credit line to the material. If material is not included in the article's Creative Commons licence and your intended use is not permitted by statutory regulation or exceeds the permitted use, you will need to obtain permission directly from the copyright holder. To view a copy of this licence, visit http://creativecommons.org/licenses/by/4.0/. 
therefore only indicated in selected indications and is not justifiable for periodic, postoperative implant monitoring.

In addition to radiographs, ultrasonography is a promising non-invasive, inexpensive, painless, and radiationfree method for imaging hard and soft tissue at implants. Especially, an ultrasound device with a high spatial resolution probe (ZS3 system and L30-8 probe, Mindray, Mountain View, CA) the size of a toothbrush (30x $18 \times$ $12 \mathrm{~mm})$, co-developed between the University of
Michigan and Mindray of North America, demonstrated a high correlation between the ultrasound, clinical and radiological measurements (Figs. 1 and 2). These images can provide valuable additional information for the assessment of peri-implant soft and hard tissue [8-10].

The presented case series of patients with peri-implant soft and hard tissue defects is the first publication of such cases obtained and imaged outside the University of Michigan using ultrasonography with high spatial resolution of up to $60 \mu \mathrm{m}$.

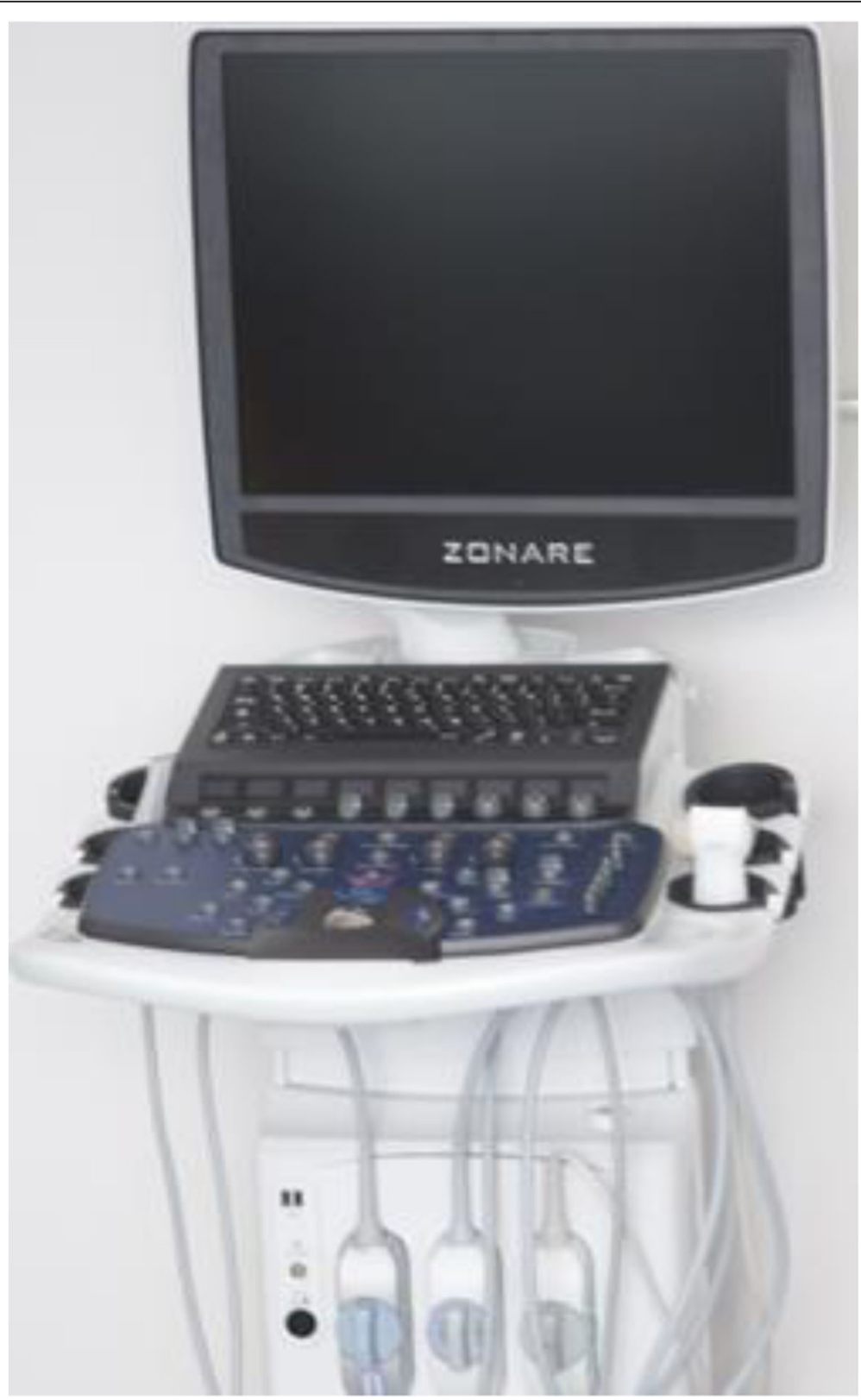

Fig. 1 Ultrasound device, model ZS 3 (Mindray Innovation Center, Mindray North America, San Jose, CA, USA) 


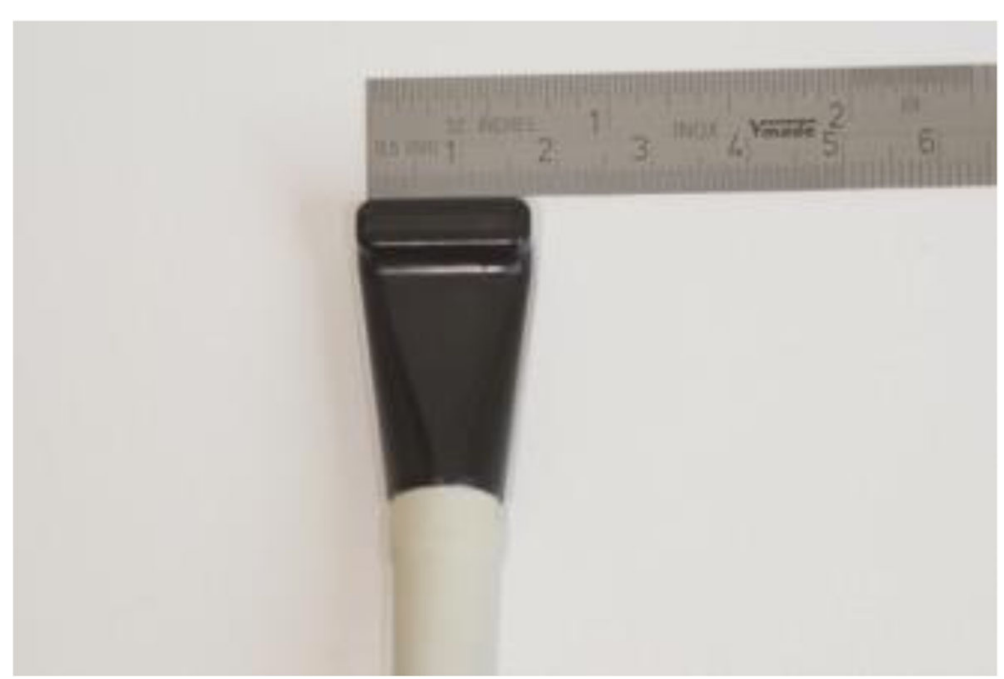

Fig. 2 High-frequency probe (up to $60 \mu \mathrm{m}$, model L30-8, Mindray Innovation Center, Mindray North America, San Jose, CA, USA) with the size of a toothbrush $(30 \times 18 \times 12 \mathrm{~mm})$

\section{Case presentation}

\section{Case 1}

In 2013, a 61-year-old patient (male) was referred to the Dental School of Medicine, Marburg/Lahn, Germany. The general medical history showed no evidence of systemic disease, and according to the selfreport, there was no nicotine or alcohol consumption. A familial increased incidence of periodontal disease could not be ruled out because both parents had been edentulous at the age of 40 . In the mandible, all teeth except teeth 44 and 45 were not worthy of preservation and removed. After a healing period of 6 months, 3 implants (Nobel Biocare; Nobel Replace Straight Groovy, Zürich, Swiss) in the third quadrant and one implant in the four quadrant with lengths of 10 to $11.5 \mathrm{~mm}$ and a diameter of 3.5 or $4 \mathrm{~mm}$ were inserted into the mandible according to the traditional delayed protocol. The 2nd stage surgery was performed after a healing period of 3 months.

The prosthetic appliance according to the doublecrown concept was provided at the Dental School of Medicine, Philipps-University, Marburg/Lahn [34].

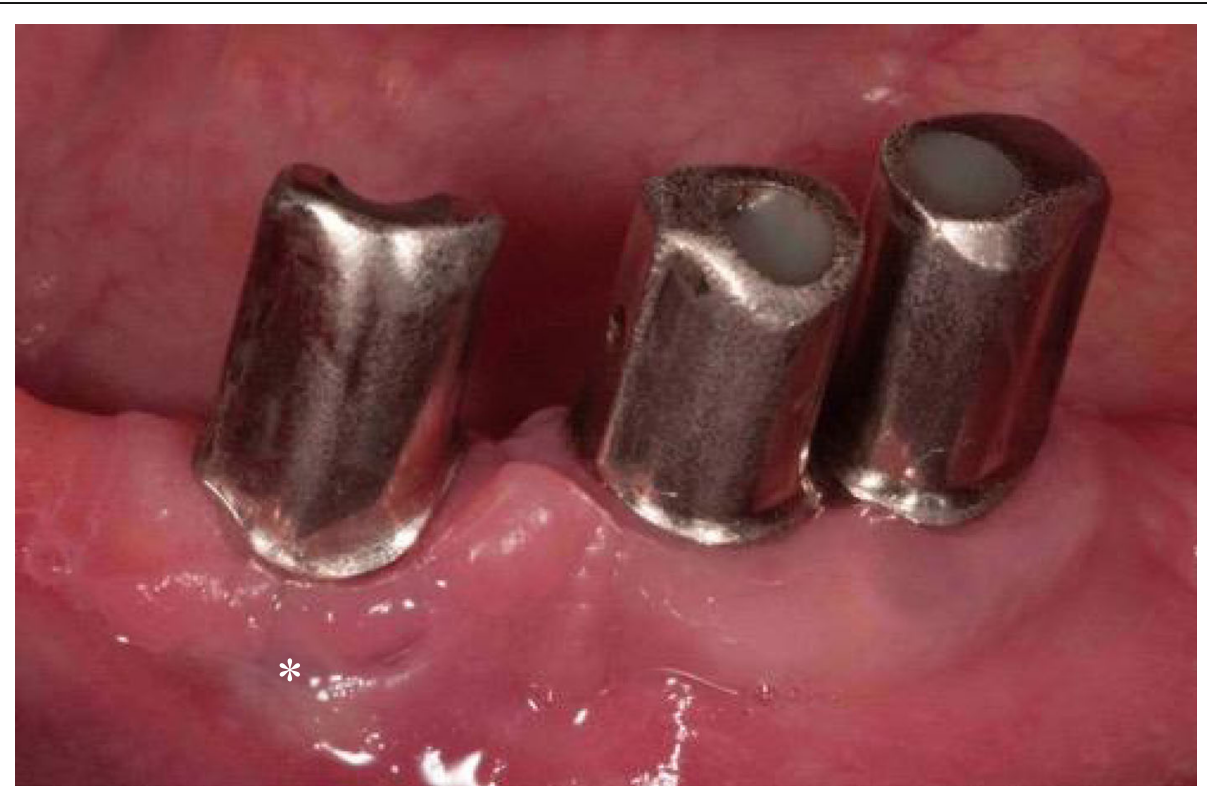

Fig. 3 The clinical findings 7 years after insertion of the superstructure showed at the implants with primary crowns no soft tissue recessions and the keratinized mucosa was $>1 \mathrm{~mm}$. The implant in region 33 showed a blue-livid discoloration buccally (marked by an asterisk) 
The clinical findings 7 years after insertion of the superstructure showed no soft tissue recessions at the implants with primary crowns and the keratinized mucosa was $>1 \mathrm{~mm}$ (Fig. 3). The implant in region 33 showed a blue-livid discoloration buccally.

The intraoral radiograph using the long-cone technique and the Rinn system (XCP Instruments, Rinn Corporation Elgin, IL, USA) showed horizontal and vertical bone loss at all implants 7 years after insertion of the superstructure (Fig. 4). At the implant in region 33, the mesial and distal crestal bone loss was up to the 6th thread, at implant in region 34 to the 4th thread, and at the implant in region 35 to the 5 th thread.

For ultrasonography the probe was placed buccally as parallel as possible to the longitudinal axis of the implant (Fig. 5). After identification of the implant surface, the probe was cranio-caudally aligned along this longitudinal axis so that parts of the superstructure, the exposed implant surface, and adjacent hard and soft tissue were imaged simultaneously. The intraoral application of ultrasound on implants means imaging of tissue immediately adjacent to the probe aperture. Therefore, a standoff pad (Parker Aquaflex ${ }^{\circ}$ Ultrasound Gel Pad, New Jersey, USA) was used as forward section, to place the region on interest into the elevational focus of the probe $(7 \mathrm{~mm})$. Furthermore, the probe was placed inside a single-use latex cover, which acted as a mechanical barrier for infection control purposes. The thickness of the pad is individually adjustable and the pad is relatively volume stable compared to conventional ultrasound gels. Since the gel pad is homogeneous and free of air inclusions, artifact formation is reduced. In addition, it compensates for unevenness and thus ensures an even pressure distribution.

Ultrasonic imaging at the implant in region 33 revealed buccal crestal bone loss up to the 6th thread, at implant in region 34 to the 3rd thread, and at the implant in region 35 to the 2nd thread (Fig. 6a-c).

The intraoperative situation at the implant in region 33 showed calculus and buccal bone loss up to the 6th thread (Fig. 7a). At the implant in region 34, the buccal crestal bone loss was up to the 3rd thread. The distance from the crestal bone to the abutment implant connection was $6 \mathrm{~mm}$ (Fig. 7b). At the implant in region 35, the crestal buccal bone loss was up to the 2nd thread (Fig. 7c).

\section{Case 2}

In 2004, a 29-year-old patient (male) was referred to the Dental School of Medicine, Marburg/Lahn, Germany. The general medical history showed no evidence of systemic disease, and according to the self-report, there was no nicotine or alcohol consumption. A familial increased incidence of periodontal disease could not be ruled out because both parents had been edentulous at the age of 30. In the maxilla, all teeth were not worthy of

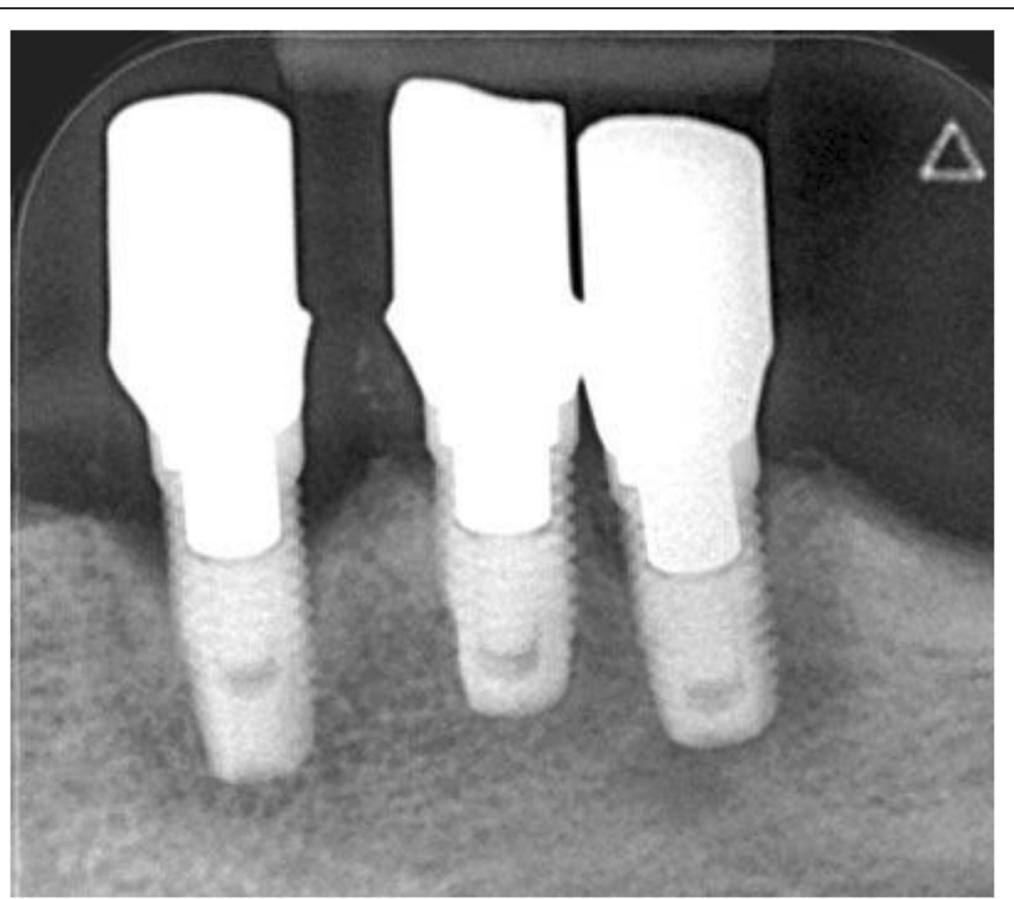

Fig. 4 The intraoral radiograph 7 years after insertion of the superstructure showed horizontal and vertical bone loss at all implants. At the implant in region 33, the mesial and distal crestal bone loss reached up to the 6 th thread, at implant in region 34 to the 4 th thread, and at the implant in region 35 to the 5 th thread 


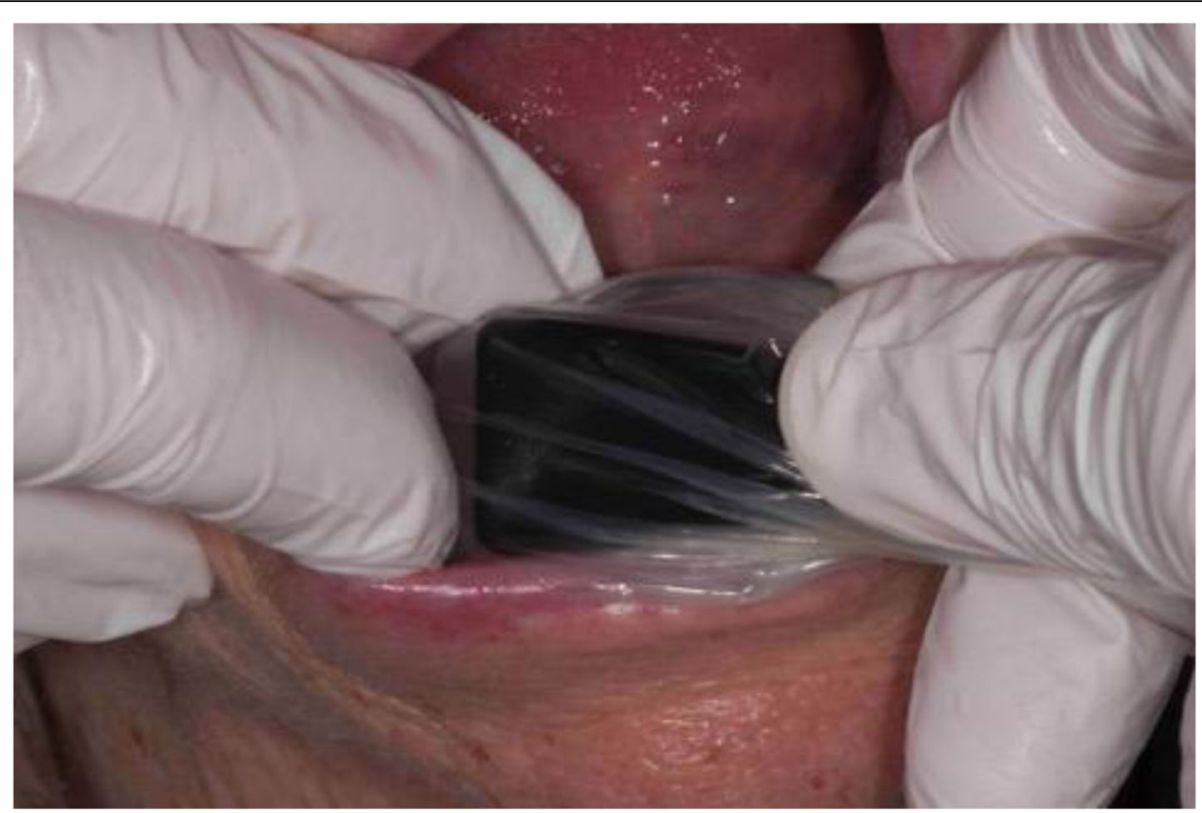

Fig. 5 Intraoral placement of the here reported high-resolution ultrasound probe (up to $60 \mu \mathrm{m}$ ) with protective cover and gel standoff pad (not visible)

preservation and removed. After a healing period of 6 months, 3 implants (Nobel Biocare; Nobel Replace Straight Groovy, Zürich, Swiss) in the first quadrant and 2 implants in the second quadrant with lengths of 10 to $13 \mathrm{~mm}$ and a diameter of 3.5 or $4 \mathrm{~mm}$ were inserted according to the traditional delayed protocol. The 2nd stage surgery was performed after a healing period of 6 months. The prosthetic appliance according to the double-crown concept and the 3- to 6-month recall schedule was provided at the Dental School of Medicine,
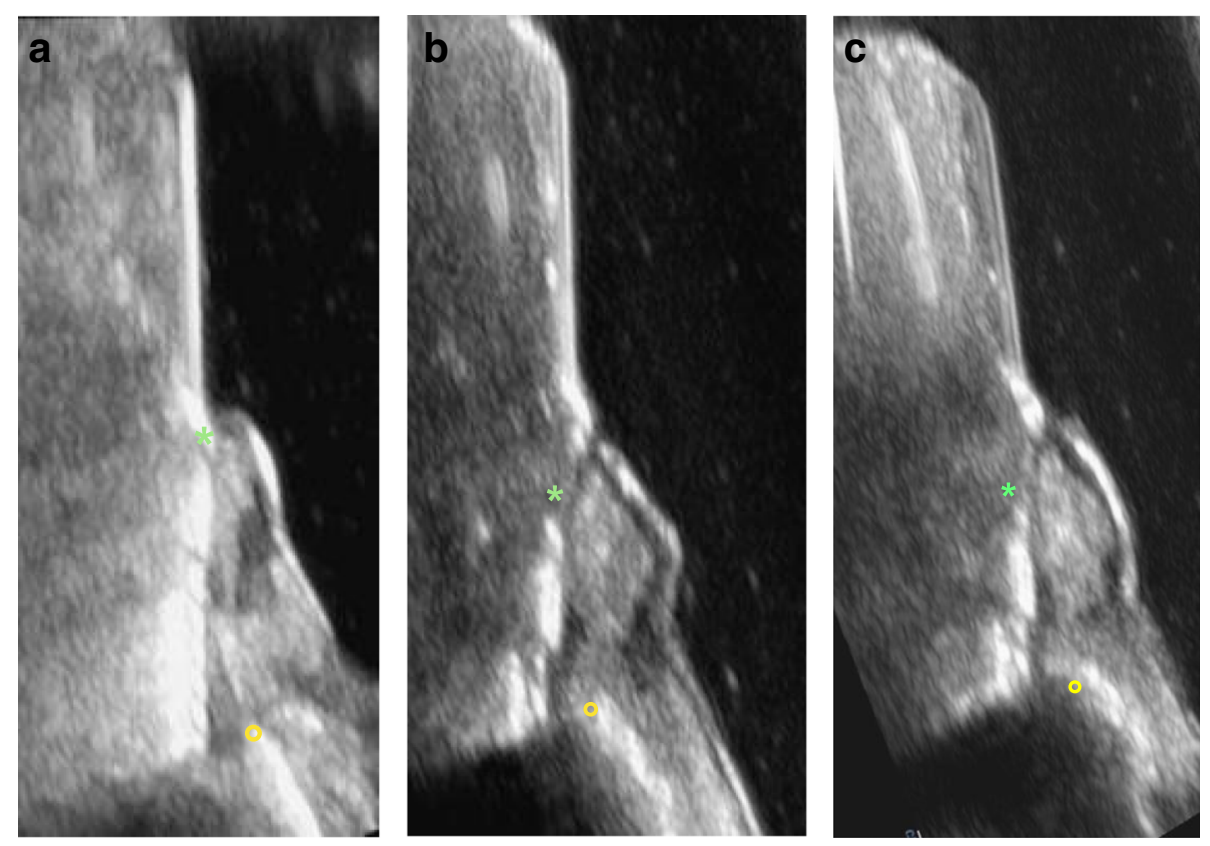

Fig. 6 a Ultrasonic imaging at the implant in region 33 revealed buccal bone loss up to the 6th thread (asterisk marks the implant-abutment interface; circle marks the bone). b Ultrasonic imaging at the implant region 34 revealed buccal bone loss up to the 3rd implant thread (asterisk marks the implant-abutment interface; circle marks the bone). c Ultrasonic imaging at the implant region 35 revealed buccal bone loss up to the 2nd implant thread (asterisk marks the implant-abutment interface; circle marks the bone) 

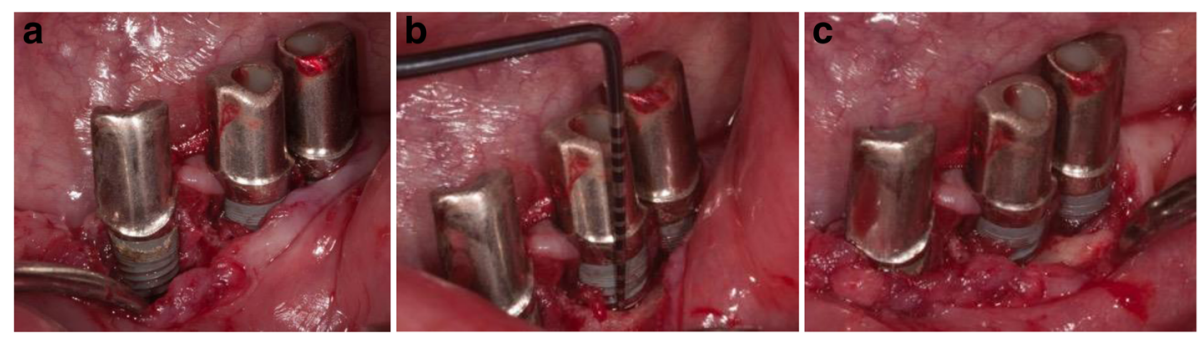

Fig. 7 a The Intraoperative situation at the implant in region 33 showed calculus and buccal crestal bone loss up to the 6th thread. b At the implant in region 34, the buccal crestal bone loss was up to the 3rd thread. The distance from the crestal bone to the abutment implant connection was $6 \mathrm{~mm}$. c At the implant in region 35, the buccal crestal bone loss reached up to the 2nd thread

Philipps-University, Marburg/Lahn, as described in case report 1.

The clinical findings 16 years after insertion of the superstructure showed at the implants with primary crowns slight recessions of the soft tissue and the keratinized mucosa was $>1 \mathrm{~mm}$ (Fig. 8a). The PD at the implants was $6-10 \mathrm{~mm}$ with BOP and suppuration on light pressure at the implant in region 14 (Fig. 8b).

The intraoral radiograph 16 years after insertion of the superstructure showed horizontal and vertical bone loss up to the 10th thread at all implants (Fig. 9).

Ultrasonic imaging at the implant in region 14 revealed buccal crestal bone loss up to the 12th thread and at implant in region 13 to the 14th thread (Fig. 10a, b). The region of interest at the implant in region 12 could not be visualized from the buccal side due to its anatomical situation (subnasal position). Imaging palatal to the implant showed bone loss up to the 13th thread. The palatal image is severely distorted because it was not possible to place the probe parallel to the implant on the oblique palate, and so it was impossible to visualize the apical bone edge (Fig. 10c).

The intraoperative situation at the implant in region 14 and 13 showed buccal bone loss far beyond the 6th thread (Fig. 11).

\section{Case 3}

In 2020, a 68-year-old patient (female) was referred to the Dental School of Medicine, Marburg/Lahn, Germany. The general medical history showed no evidence of systemic disease, and according to the self-report, there was no nicotine or alcohol consumption.

In 2014, one implant (Camlog, Conelog, Screw Line, $\varnothing$ $3.3 \mathrm{~mm}$, length $11 \mathrm{~mm}$ ) was inserted in the mandible in region 43 according to the traditional delayed protocol. The 2nd stage surgery was performed after a healing time of 3 months. The prosthetic appliance, according to the double-crown concept at the tooth 33 and the implant in region 43 , was provided at a private dental office. After insertion of the superstructure, there was no regular recall schedule.

Clinical findings at the implant 6 years after insertion of the superstructure showed a slight buccal soft tissue recession; keratinized mucosa was $>1 \mathrm{~mm}$ (Fig. 12a). The probing depth was $7 \mathrm{~mm}$ with BOP and suppuration (Fig. 12b).

The intraoral radiograph 6 years after insertion of the superstructure showed horizontal and vertical bone loss at the implant. The crestal bone loss was up to the 6th thread (Fig. 13).
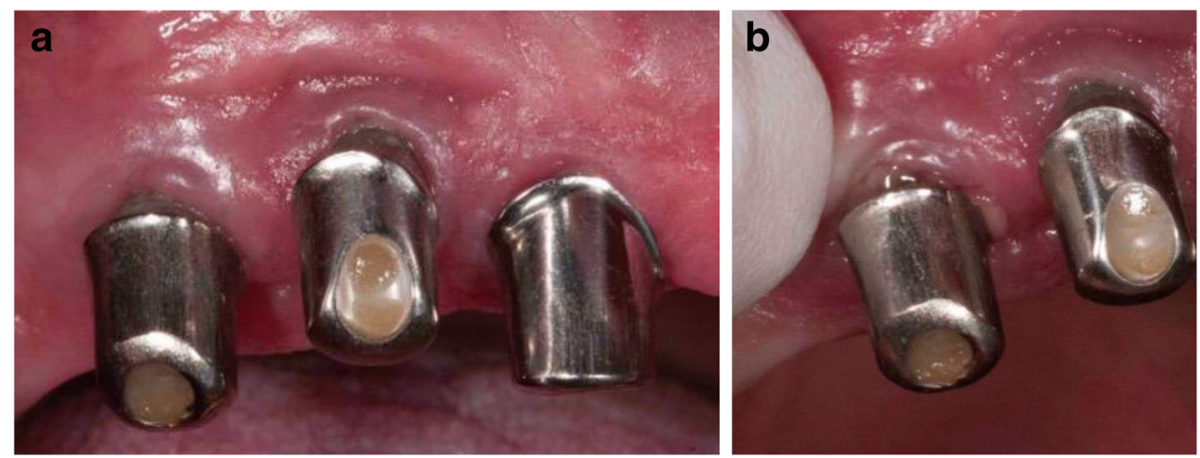

Fig. 8 a The clinical findings 16 years after insertion of the superstructure showed at the implants with primary crowns slight recessions of the soft tissue and the keratinized mucosa was $>1 \mathrm{~mm}$. b The implant in region 14 showed suppuration on light pressure 


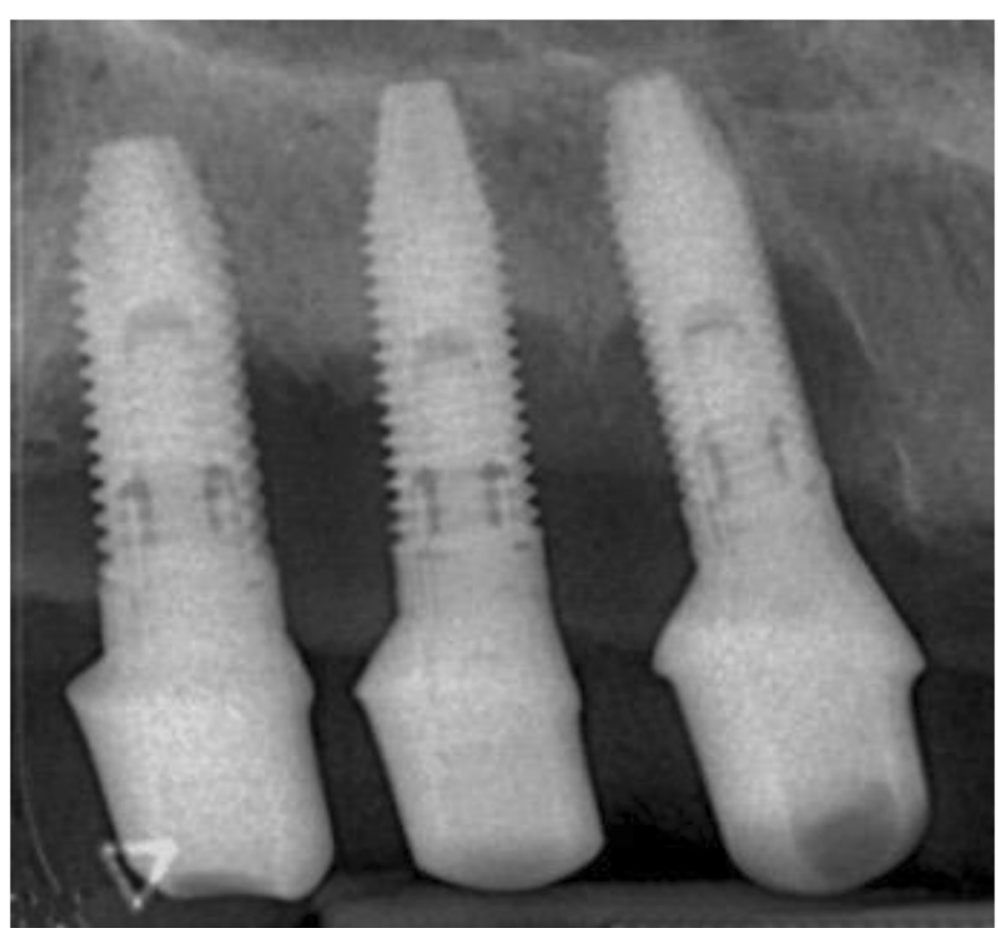

Fig. 9 The intraoral radiographs 16 years after insertion of the superstructure showed horizontal and vertical bone loss up to the 10 th thread at all implants

Ultrasonic imaging of the implant in region 43 showed a crestal bone loss buccally up to the 5 th thread with a deep infracrestal bone loss (Fig. 14). The implant surface in the infrabony region can system-related not be validly assessed. The free-standing crater-forming bone edge does not seem to be able to completely conceal the underlying defect, but the titanium surface behind is no longer reliably displayed.

The intraoperative situation at the implant in region 43 reveals buccal bone loss up to the 6rd thread. The horizontal bone defect is $8 \mathrm{~mm}$, and the vertical defect 3 mm (Fig. 15a, b).
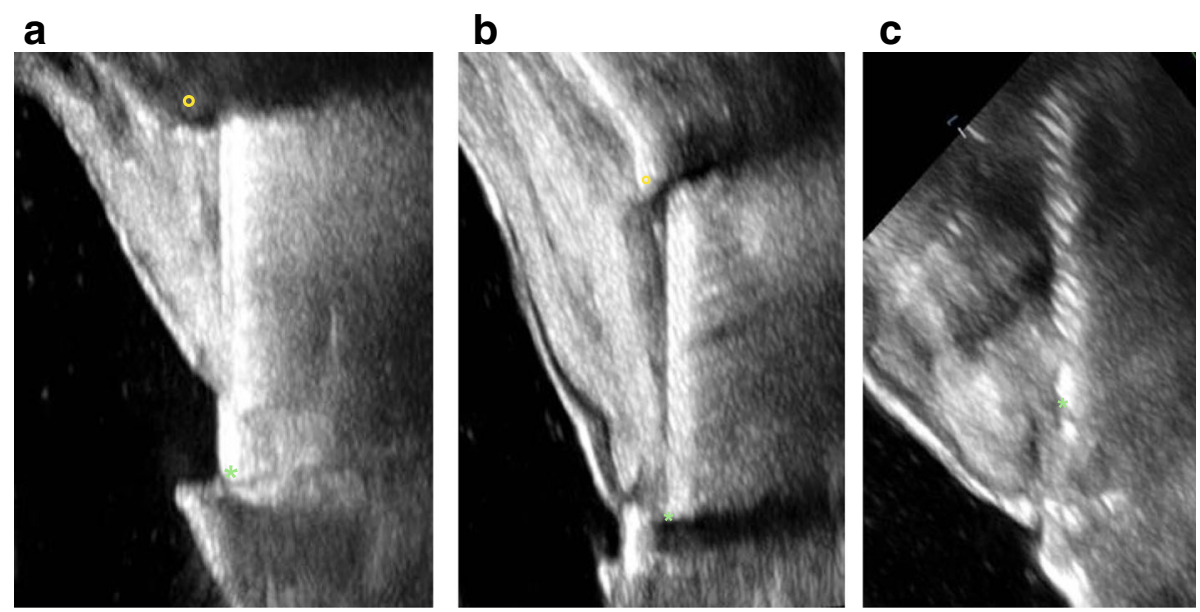

Fig. 10 a Ultrasonic imaging at the implant in region 14 revealed a buccal bone loss up to the 12th thread (asterisk marks the implant-abutment interface; circle marks the bone). b Ultrasonic imaging at the implant in region 13 revealed a buccal bone loss up to the 14th thread (asterisk marks the implant-abutment interface; circle marks the bone). c Ultrasonic imaging at the implant in region 12 could not be visualized from the buccal side due to its anatomical situation (subnasal position). Imaging palatal to the implant showed bone loss up to the 13th thread. The palatal image is severely distorted because it was not possible to place the probe parallel to the implant on the oblique palate, and so it was impossible to visualize the apical bone edge (asterisk marks the implant-abutment interface) 


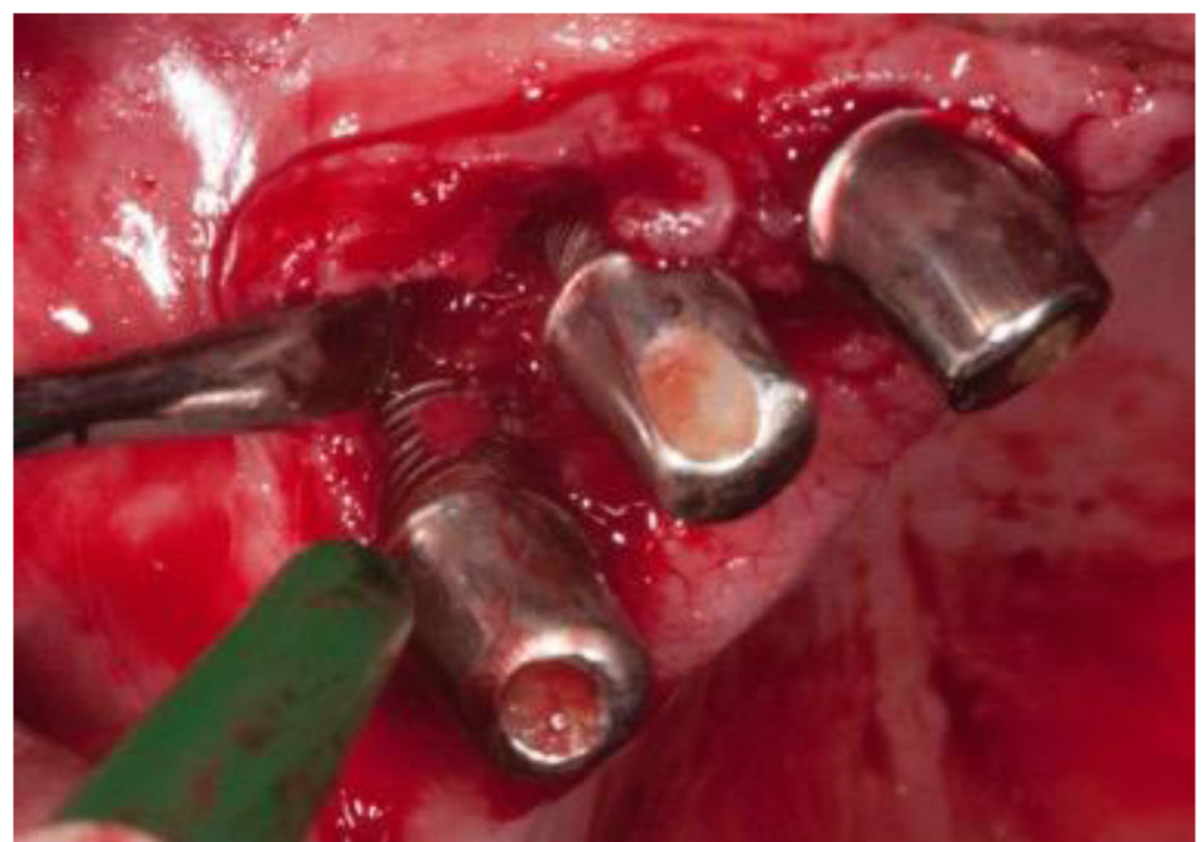

Fig. 11 The intraoperative situation at the implant in region 14 and 13 showed buccal bone loss far beyond the 6th thread

\section{Discussion}

The first data of diagnostic ultrasound in dentistry reported in the literature seems to be in 1963 by Baum et al., who used a $15-\mathrm{MHz}$ transducer with the aim of visualizing the interior structures of teeth [2]. Since then, many different ultrasound applications in dentistry have been reported [31, 39]. For measuring the thickness of periodontal soft tissue, the value of ultrasound images has already been investigated [35-37]. Further studies have evaluated the use of ultrasound in the diagnosis of alveolar bone and tooth structure $[3,5,16,27,38,40$, $41,44,50]$.
The discovery of new applications of ultrasound seems to be ongoing. In 2014, Vollborn et al. [53] developed a high-frequency ultrasonic device for intraoral digitization of prepared teeth to counteract problems due to blood, saliva, and the gingival retraction procedure in case of subgingival preparation margins.

All of these studies demonstrate the promising future of ultrasonography as a diagnostic imaging tool in dentistry. However, many of these studies were performed with large ultrasound probes with a resolution of larger than $75 \mu \mathrm{m}(20$ $\mathrm{MHz}$ ), which are reduced to extra oral use and have limited applicability in routine dental diagnostics [31,39].
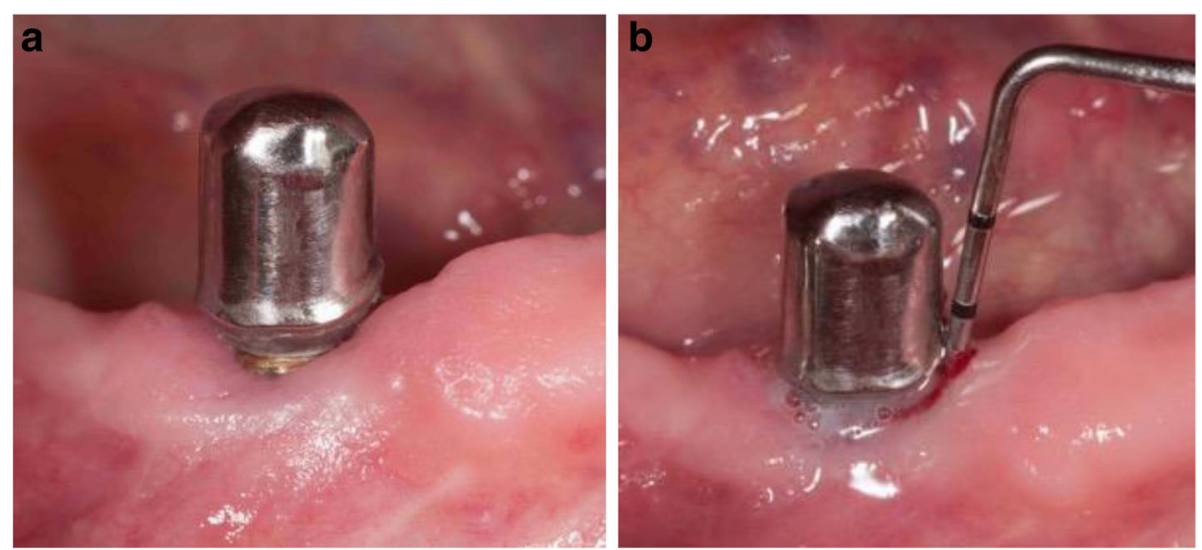

Fig. 12 a The clinical findings at the implant 6 years after insertion of the superstructure showed a slight buccal recession of the soft tissue. The keratinized mucosa was $>1 \mathrm{~mm}$. b The probing depth was $7 \mathrm{~mm}$ with BOP and suppuration 


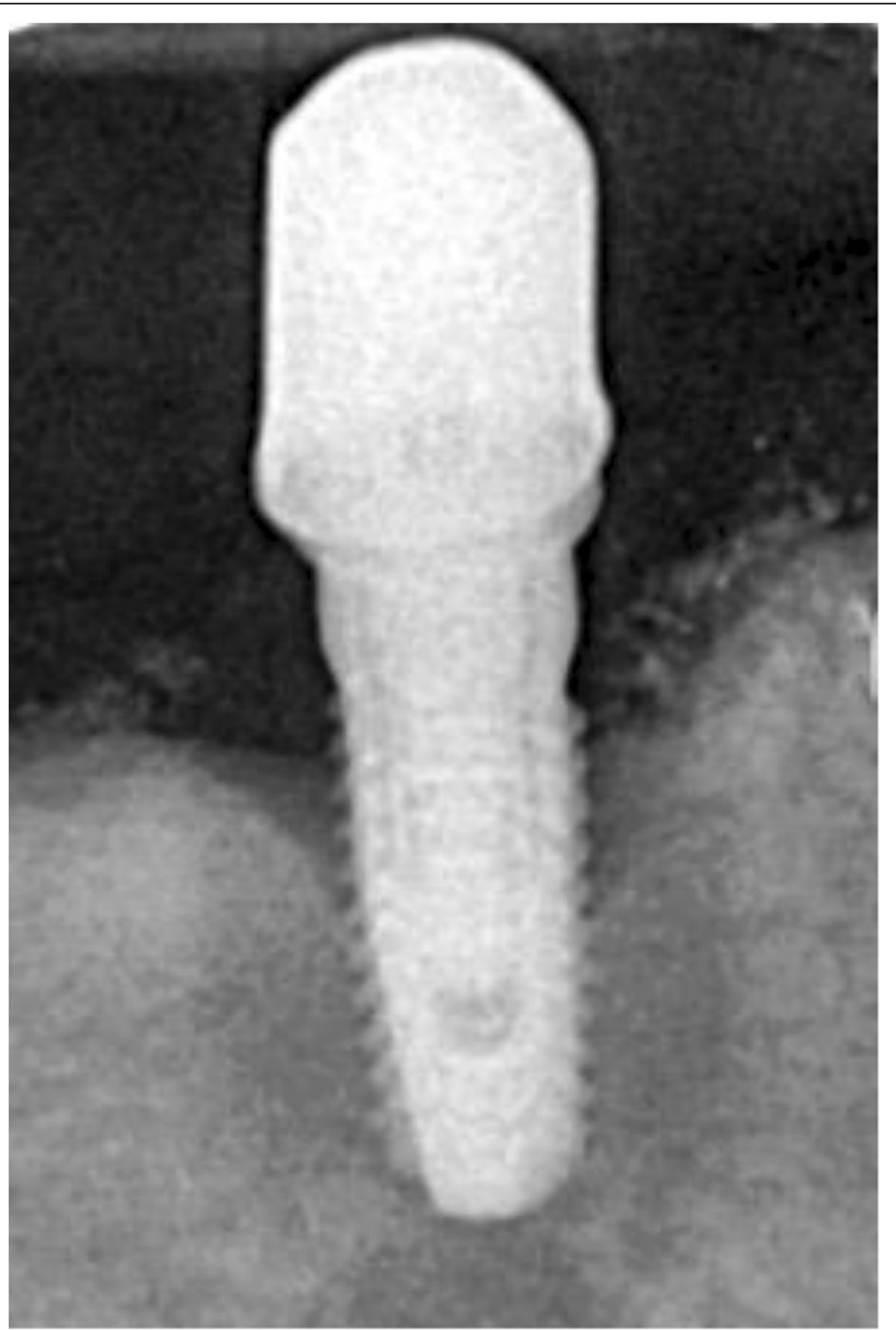

Fig. 13 The intraoral radiograph 6 years after insertion of the superstructure showed horizontal and vertical bone loss at the implant. The crestal bone loss was up to the 6 th thread.

In the presented case series, ultrasonography of soft tissue and crestal bone level was performed with an intraoral capable high-resolution probe (up to $60 \mu \mathrm{m}$, frequency range 8 to $30 \mathrm{MHz}$ ). In all patients, the soft tissue and bone crest could be localized buccally on almost all implants. These results confirm other clinical studies that have demonstrated accurate soft tissue and bone level imaging using ultrasound scanning with a 25$\mathrm{MHz}$ probe $[8,8]$. In one clinical study, the height of the interdental papilla, width and height of soft tissue, width and height of the mucosa above the bone in tooth spaces, and crestal bone level were determined with a 24-MHz ultrasound probe [48]. The aim was to evaluate the correlation and accuracy of ultrasound in measuring periodontal dimensions, compared to direct clinical CBCT methods. The results revealed that ultrasonic imaging can be valuable for accurate and real-time periodontal diagnosis. In another study at implants in human native jaws, the dimension of soft tissue was determined by ultrasonic measurements [8]. The width and height of the soft tissue showed a high correlation with the $\mathrm{CBCT}$ and the direct clinical measurement with a periodontal probe.

A systematic review identified several applications of ultrasonography in the implant treatment phases [4]. In the planning phase, vital structures as well as soft and hard tissue biotype can be identified by ultrasound. Furthermore, the ridge width, bone density, and cortical 


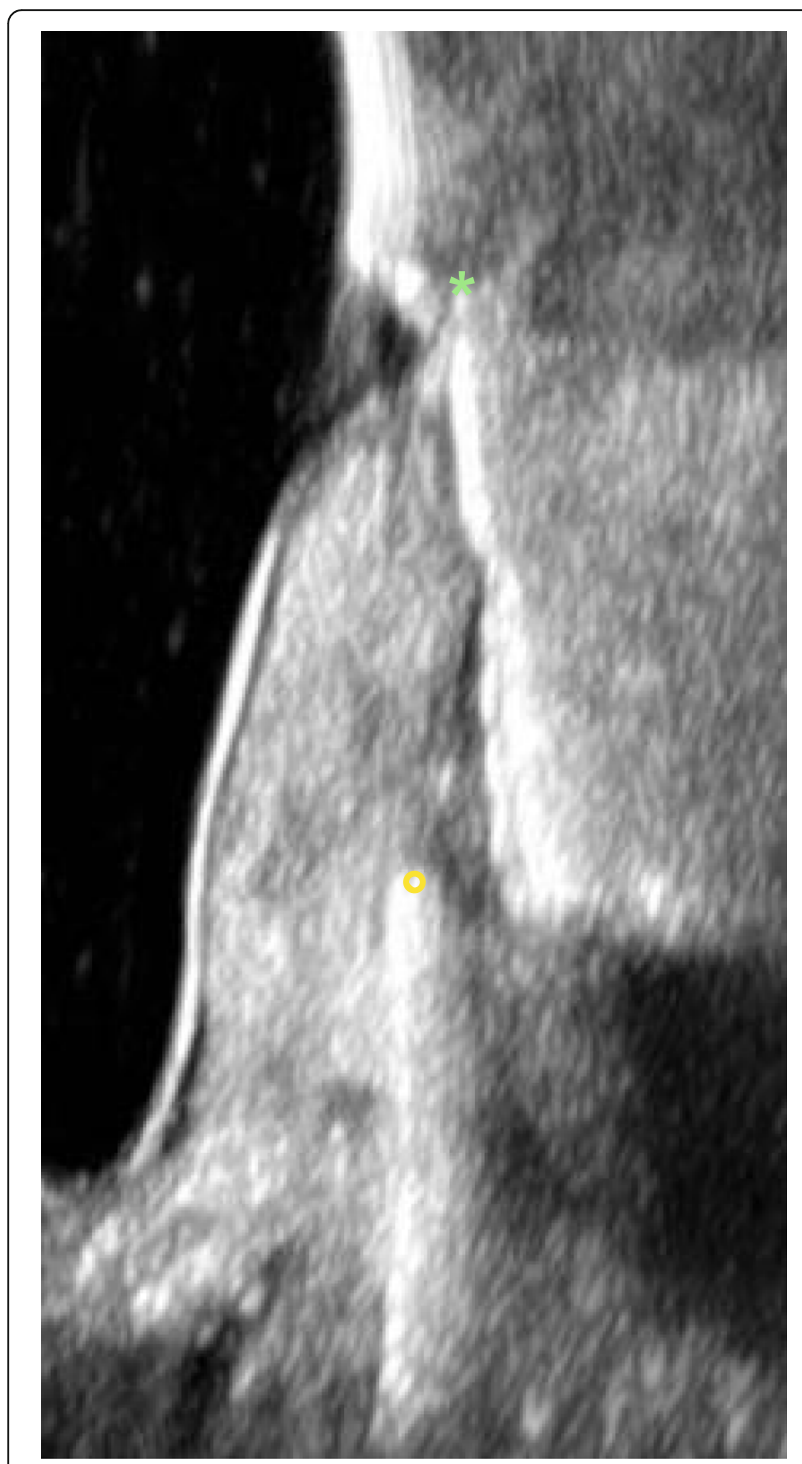

Fig. 14 Ultrasonic imaging at the implant in region 43 revealed a buccal bone loss up to the 5th thread with an infracrestal bone loss (asterisk marks the implant-abutment interface; circle marks the bone)

bone thickness may be evaluated. In the surgical phase, vital structures can be identified and primary stability can be indicated. In the follow-up phase, the crestal bone level around implants can be evaluated and implant-bone stability can be indicated.

These results demonstrate that intraoral ultrasonic imaging can be used predictably for soft tissue diagnostics at teeth and implants without concerns about ionizing radiation. In particular, prior to surgical treatment for bone and soft tissue regeneration, ultrasonography of the soft tissue could provide valuable additional information, since the success rates are influenced by the soft tissue biotype [11]. Ultrasonography could also be valuable in peri-implant diagnostics, since sufficient width and thickness of soft tissue is a prerequisite for the longterm success of implants and can be surgically optimized in case of a diagnosed deficiency [15, 24-26]. Furthermore, in the three-dimensional planning of implants, the imaging of the crestal bone with overlying soft tissue can improve the predictability of an esthetic and functional emergence profile of prosthetic restorations.

In addition to the imaging of crestal bone level and soft tissue dimensions, the validity of ultrasonography to determining the lingual nerve in human cadavers and live humans was tested [1]. The results showed that ultrasound accurately measured mandibular lingual soft tissue structures on cadavers and the lingual nerve on live humans.

In addition to morphological and topographical imaging of the soft tissue, a recently published study investigated functional ultrasonography with the same probe as here reported [8]. In one patient, each with a healthy implant, an implant with mucositis and peri-implantitis, and an implant with soft tissue and bone loss without signs of inflammation, blood flow to the peri-implant soft tissue was visualized. The results showed that the ultrasonic imaging not only provides anatomical crosssectional images, but also can show the blood flow in the soft tissue. This functional imaging mode (color flow and color power mode), in conjunction with photoacoustics, could be of particular interest in the future in order to differentiate in peri-implant tissue the changes in active blood vessels with respect to the ratio of oxygenated/deoxygenated hemoglobin and total blood volume. It should be further investigated whether such image modality combination could be used to differentiate disease activity such as different degrees of severity of peri-implantitis.

Despite the promising results with the reported highfrequency probe, ultrasonography has shown limitations in the diagnostic value of soft tissue and crestal bone level. For example, the extent and severity of crestal bone loss may influence the validity of ultrasonic imaging, since advanced bone loss $(>6 \mathrm{~mm})$ is expected to be less accurate than moderate bone loss [8]. Furthermore, infrabony defects at implants or teeth cannot be determined predictably. Application-related limitations in ultrasonography include the dependence of image quality on the technical skills of the practitioner. Certainly, clinicians will need training, either by means of continuing education or via specialty training. First of all, a coupling medium between the probe head and the surface to be scanned is required to reduce the display of air bubbles in the ultrasound images. The probe should be placed as parallel as possible to the longitudinal axis of the implant in order to prevent distortions and to get a true-scale image. In some cases, anatomical obstacles impede an appropriate probe alignment. 

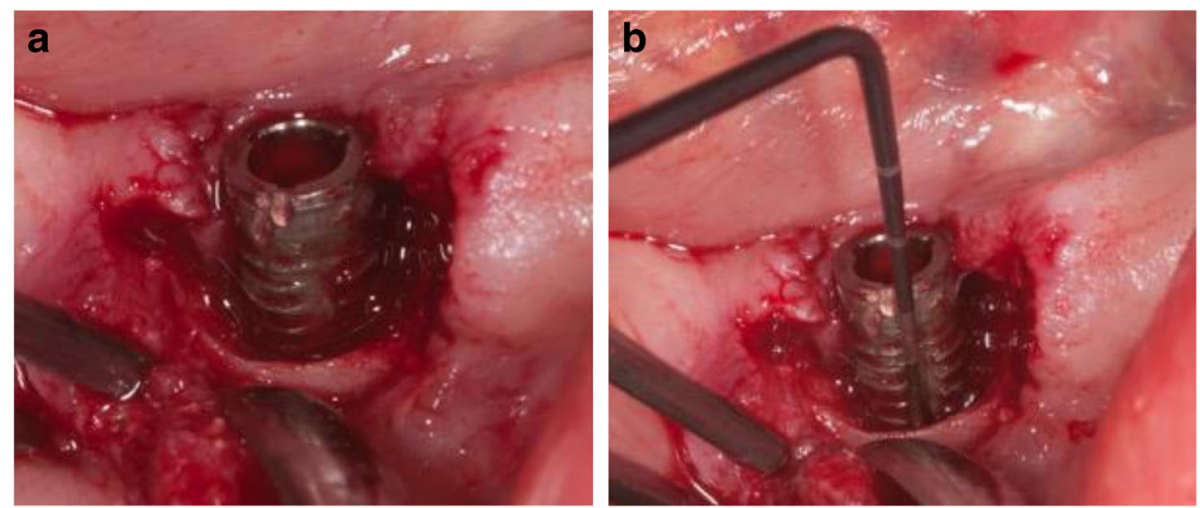

Fig. 15 a The intraoperative situation at the implant in region 43 reveals a buccal bone loss up to the 6rd thread. b The horizontal bone defect is $8 \mathrm{~mm}$, and the vertical defect $3 \mathrm{~mm}$

\section{Conclusions}

These case series demonstrate that an ultrasound device with an intra-orally functional, high-resolution probe can be used predictably for imaging of the crestal bone level and soft tissue dimensions at dental implants. Further clinical studies should evaluate the applications of non-invasive, high-resolution ultrasonography in the routine diagnostics in dentistry.

\section{Authors' contributions}

RM treated the patients. MTM and RM drafted the manuscript. ODK contributed ultrasound expertise and edited the manuscript. The authors read and approved the final manuscript.

\section{Funding}

The treatment of the patients was supported by a research grant from the Philipps-University of Marburg. Open Access funding enabled and organized by Projekt DEAL.

\section{Availability of data and materials} Not applicable.

\section{Declarations}

\section{Ethics approval and consent to participate}

No ethics application was submitted, as data was acquired during routine examinations by standard procedures. All patients provided informed consent.

\section{Consent for publication}

All patients gave their consent for publication.

\section{Competing interests}

M. Thöne-Mühling, O. D. Kripfgans, and R. Mengel state that there were no conflicts of interest.

\section{Author details}

'Department of Prosthetic Dentistry, School of Dental Medicine, Philipps-University Marburg, Georg-Voigt Str. 3, 35039 Marburg/Lahn, Germany. ${ }^{2}$ Department of Radiology, BME, and Appl. Phys., University of Michigan, 3218D Med Sci I, 1301 Catherine Street, Ann Arbor, Ml 48109-5667, USA.
Received: 19 May 2021 Accepted: 25 June 2021

Published online: 14 September 2021

\section{References}

1. Barootchi S, Chan HL, Namazi SS, Wang HL, Kripfgans OD. Ultrasonographic characterization of lingual structures pertinent to oral, periodontal, and implant surgery. Clin Oral Implants Res. 2020;31(4):352-9. https://doi.org/1 $0.1111 / \mathrm{clr} .13573$

2. Baum G, Greenwood I, Slawski S, Smirnow R. Observation of internal structures of teeth by ultrasonography. Science. 1963;139(3554):495-6. https://doi.org/10.1126/science.139.3554.495.

3. Bertram S, Emshoff R. Sonography of periimplant buccal bone defects in periodontitis patients: a pilot study. Oral Surg Oral Med Oral Pathol Oral Radiol Endod. 2008;105(1):99-103. https://doi.org/10.1016/j.tripleo.2007.01.014.

4. Bhaskar V, Chan H-L, MacEachern M, Kripfgans OD. Updates on ultrasound research in implant dentistry: a systematic review of potential clinical indications. Dentomaxillofac Radiol. 2018;47(6):20180076. https://doi.org/1 $0.1259 / d m f r .20180076$

5. Bohner L, Habor D, Tortamano P, Radermacher K, Wolfart S, Marotti J. Assessment of buccal bone surrounding dental implants using a highfrequency ultrasound scanner. Ultrasound Med Biol. 2019;45(6):1427-34. https://doi.org/10.1016/j.ultrasmedbio.2019.02.002.

6. Braut $V$, Bornstein MM, Belser U, Buser D. Thickness of the anterior maxillary facial bone wall-a retrospective radiographic study using cone beam computed tomography. Int J Periodontics Restorative Dent. 2011;31(2):12531 PMID: 21491011.

7. Chan H-L, Sinjab K, Li J, Chen Z, Wang H-L, Kripfgans OD. Ultrasonography for noninvasive and real-time evaluation of peri-implant tissue dimensions. J Clin Periodontol. 2018;45(8):986-95. https://doi.org/10.1111/jcpe.12918.

8. Chan HL, Kripfgans OD. Ultrasonography for diagnosis of peri-implant diseases and conditions: a detailed scanning protocol and case demonstration. Dentomaxillofacial Radiol. 2020;49(7):20190445. https://doi. org/10.1259/dmfr.20190445.

9. Chan HL, Sinjab K, Chung MP, Chiang YC, Wang HL, Giannobile W, et al. Non-invasive evaluation of facial crestal bone with ultrasonography. Plos One. 2017a;12(2):e0171237. https://doi.org/10.1371/journal.pone.0171237.

10. Chan HL, Wang HL, Fowlkes JB, Giannobile WV, Kripfgans OD. Non-ionizing real-time ultrasonography in implant and oral surgery: a feasibility study. Clin Oral Implants Res. 2017b;28(3):341-7. https://doi.org/10.1111/clr.12805.

11. Chao YC, Chang PC, Fu JH, Wang HL, Chan HL. Surgical site assessment for soft tissue management in ridge augmentation procedures. Int J Periodontics Restorative Dent. 2015;35(5):e75-83. https://doi.org/10.11607/ prd.2097.

12. Chrcanovic BR, Albrektsson T, Wennerberg A. Periodontally compromised vs periodontally healthy patients and dental implants: a systematic review and meta-analysis. J Dent. 2014;42(12):1509-27. https://doi.org/10.1016/j.jdent.2 014.09.013.

13. Christiaens V, De Bruyn H, Thevissen E, Koole S, Dierens M, Cosyn J. Assessment of periodontal bone level revisited: a controlled study on the diagnostic accuracy of clinical evaluation methods and intra-oral 
radiography. Clin Oral Investig. 2018;22(1):425-31. https://doi.org/10.1007/ s00784-017-2129-8.

14. Christiaens V, Jacobs R, Dierens M, Vervaeke S, De Bruyn H, Koole S, et al. Intraoral radiography lacks accuracy for the assessment of peri-implant bone level - a controlled clinical study. Eur J Oral Implantol. 2017;10(4):43541. 29234750.

15. De Bruyckere T, Eghbali A, Younes F, De Bruyn H, Cosyn J. Horizontal stability of connective tissue grafts at the buccal aspect of single implants: A 1-year prospective case series. J Clin Periodontol. 2015;42(9):876-82. https://doi.org/10.1111/jcpe.12448.

16. Degen K, Habor D, Radermacher K, Heger S, Kern JS, Wolfart S, et al. Assessment of cortical bone thickness using ultrasound. Clin Oral Implants Res. 2017;28(5):520-8. https://doi.org/10.1111/clr.12829.

17. Derks J, Tomasi C. Peri-implant health and disease. A systematic review of current epidemiology. J Clin Periodontol. 2015;42(Suppl 16):158-71. https:// doi.org/10.1111/jcpe.12334

18. Elemek E, Agrali OB, Kuru B, Kuru L. Peri-implantitis and severity level. Eur J Dent. 2020;14(1):24-30. https://doi.org/10.1055/s-0040-1701162.

19. Ferreira SD, Martins CC, Amaral SA, Vieira TR, Albuquerque BN, Cota LOM, et al. Periodontitis as a risk factor for peri-implantitis: Systematic review and meta-analysis of observational studies. J Dent. 2018;79:1-10. https://doi. org/10.1016/j.jdent.2018.09.010 Epub 2018 Nov.

20. Fienitz T, Schwarz F, Ritter L, Dreiseidler T, Becker J, Rothamel D. Accuracy of cone beam computed tomography in assessing peri-implant bone defect regeneration: a histologically controlled study in dogs. Clin Oral Implants Res. 2012;23(7):882-7. https://doi.org/10.1111/j.1600-0501.2011.02232.x.

21. Frost NA, Mealey BL, Jones AA, Huynh-Ba G. Periodontal biotype: gingival thickness as it relates to probe visibility and buccal plate thickness. J Periodontol. 2015;86(10):1141-9. https://doi.org/10.1902/jop.2015.140394.

22. Haas LF, Zimmermann GS, De Luca CG, Flores-Mir C, Corrêa M. Precision of cone beam $C T$ to assess periodontal bone defects: a systematic review and meta-analysis. Dentomaxillofac Radiol. 2018;47(2):20170084. https://doi.org/1 $0.1259 / \mathrm{dmfr} .20170084$

23. Kehl M, Swierkot K, Mengel R. Three-dimensional measurement of bone loss at implants in patients with periodontal disease. J Periodontol. 2011;82(5): 689-99. https://doi.org/10.1902/jop.2010.100318.

24. Lin GH, Chan HL, Wang HL. The significance of keratinized mucosa on implant health: a systematic review. J Periodontol. 2013:84(12):1755-67. https://doi.org/10.1902/jop.2013.120688.

25. Linkevicius T, Apse P, Grybauskas S, Puisys A. The influence of soft tissue thickness on crestal bone changes around implants: a 1-year prospective controlled clinical trial. Int J Oral Maxillofac Implants. 2009;24(4):712-9 PMID: 19885413.

26. Linkevicius T, Apse P, Grybauskas S, Puisys A. Influence of thin mucosal tissues on crestal bone stability around implants with platform switching: a 1-year pilot study. J Oral Maxillofac Surg. 2010;68(9):2272-7. https://doi.org/1 0.1016/j.joms.2009.08.018.

27. Löst C, Irion KM, Nüssle W. Determination of the facial/oral alveolar crest using RF-echograms. An in vitro study on the periodontium of pigs. J Clin Periodontol. 1989;16(8):539-44. https://doi.org/10.1111/j.1600-051x.1989. tb02333.x.

28. Loubele M, Bogaerts $R$, Van Dijck E, Pauwels $R$, Vanheusden $S$, Suetens $P$, et al. Comparison between effective radiation dose of CBCT and MSCT scanners for dentomaxillofacial applications. Eur J Radiol. 2009;71(3):461-8. https://doi.org/10.1016/.ejrad.2008.06.002.

29. Ludlow JB, Davies-Ludlow LE, Brooks SL, Howerton WB. Dosimetry of 3 CBCT devices for oral and maxillofacial radiology: CB Mercuray, NewTom $3 G$ and i-CAT. Dentomaxillofac Radiol. 2006;35(4):219-26. https://doi.org/10.12 59/dmfr/14340323 Erratum in: Dentomaxillofac Radiol. 2006 Sep;35(5):392. PMID: 16798915

30. Ludlow JB, Ivanovic M. Comparative dosimetry of dental CBCT devices and 64-slice CT for oral and maxillofacial radiology. Oral Surg Oral Med Oral Pathol Oral Radiol Endod. 2008;106(1):106-14. https://doi.org/10.1016/j. tripleo.2008.03.018

31. Marotti J, Heger S, Tinschert J, Tortamano P, Chuembou F, Radermacher K, et al. Recent advances of ultrasound imaging in dentistry. A review of the literature. Oral Surg Oral Med Oral Pathol Oral Radiol. 2013;115(6):819-32. https://doi.org/10.1016/.0000.2013.03.012

32. Mengel R, Candir M, Shiratori K, Flores-de-Jacoby L. Digital volume tomography in the diagnosis of periodontal defects: an in vitro study on native pig and human mandibles. J Periodontol. 2005;76(5):665-73. https:// doi.org/10.1902/jop.2005.76.5.665.

33. Mengel R, Kruse B, Flores-de-Jacoby L. Digital volume tomography in the diagnosis of peri-implant defects: an in vitro study on native pig mandibles. J Periodontol. 2006;77(7):1234-41. https://doi.org/10.1902/jop.2006.050424.

34. Mengel R, Wendt J, Pelseka B. Prosthodontic treatment outcomes in periodontally compromised patients: a 6- to 20-year long-term cohort study. Int J Prosthodont. 2019;32(2):153-61. https://doi.org/10.11607/ijp.5917.

35. Müller HP, Schaller N, Eger T. Ultrasonic determination of thickness of masticatory mucosa: a methodologic study. Oral Surg Oral Med Oral Pathol Oral Radiol Endod. 1999;88(2):248-53. https://doi.org/10.1016/s1079-2104 (99)70123-x.

36. Müller HP, Könönen E. Variance components of gingival thickness. J Periodontal Res. 2005;40(3):239-44. https://doi.org/10.1111/j.1600-0765.2005. 00798.x.

37. Müller HP, Barrieshi-Nusair KM, Könönen E. Repeatability of ultrasonic determination of gingival thickness. Clin Oral Investig. 2007;11(4):439-42. https://doi.org/10.1007/s00784-007-0125-0.

38. Nguyen KT, Le LH, Kaipatur NR, Major PW. Imaging the cemento-enamel junction using a 20-MHz ultrasonic transducer. Ultrasound Med Biol. 2016a; 42(1):333-8. https://doi.org/10.1016/j.ultrasmedbio.2015.09.012.

39. Nguyen KT, Pachêco-Pereira C, Kaipatur NR, Cheung J, Major PW, Le LH. Comparison of ultrasound imaging and cone-beam computed tomography for examination of the alveolar bone level: a systematic review. Plos One. 2018;13(10):e0200596. https://doi.org/10.1371/journal.pone.0200596.

40. Nguyen KT, Le LH, Kaipatur NR, Zheng R, Lou EH, Major PW. High-resolution ultrasonic imaging of dento-periodontal tissues using a multi-element phased array system. Ann Biomed Eng. 2016b;44(10):2874-86. https://doi. org/10.1007/s10439-016-1634-2.

41. Palou ME, McQuade MJ, Rossmann JA. The use of ultrasound for the determination of periodontal bone morphology. J Periodontol. 1987;58(4): 262-5. https://doi.org/10.1902/jop.1987.58.4.262.

42. Pauwels R, Beinsberger J, Collaert B, Theodorakou C, Rogers J, Walker A, et al. Effective dose range for dental cone beam computed tomography scanners. Eur J Radiol. 2012;81(2):267-71. https://doi.org/10.1016/j.ejrad.201 0.11.028.

43. Ritter L, Elger MC, Rothamel D, Fienitz T, Zinser M, Schwarz F, et al. Accuracy of peri-implant bone evaluation using cone beam $\mathrm{CT}$, digital intra-oral radiographs and histology. Dentomaxillofac Radiol. 2014;43(6):20130088. https://doi.org/10.1259/dmfr.20130088.

44. Salmon B, Le Denmat D. Intraoral ultrasonography: development of a specific high-frequency probe and clinical pilot study. Clin Oral Investig. 2012;16(2):643-9. https://doi.org/10.1007/s00784-011-0533-z.

45. Salvi GE, Cosgarea R, Sculean A. Prevalence and mechanisms of peri-implant disease. J Dent Res. 2017;96(1):31-7. https://doi.org/10.1177/002203451 6667484.

46. Sanz M, Chapple IL. Working Group 4 of the VIII European Workshop on Periodontology. Clinical research on peri-implant diseases: Consensus report of Working Group 4. J Clin Periodontol. 2012;39(Suppl 12):202-6. https://doi. org/10.1111/j.1600-051X.2011.01837.X.

47. Sheridan RA, Chiang YJ, Decker AM, Sutthiboonyapan P, Chan HL, Wang HL. The effect of implant-induced artifacts on interpreting adjacent bone structures on cone-beam computed tomography scans. Implant Dent. 2018; 27(1):10-4. https://doi.org/10.1097/ID.0000000000000684.

48. Tattan M, Sinjab K, Lee E, Arnett M, Oh TJ, Wang HL, et al. Ultrasonography for chairside evaluation of periodontal structures: A pilot study. Periodontol. 2020;91(7):890-9. https://doi.org/10.1002/JPER.19-0342.

49. Timock AM, Cook V, McDonald T, Leo MC, Crowe J, Benninger BL, et al. Accuracy and reliability of buccal bone height and thickness measurements from cone-beam computed tomography imaging. Am J Orthod Dentofacial Orthop. 2011;140(5):734-44. https://doi.org/10.1016/.jajodo.2011.06.021.

50. Tsiolis Fl, Needleman IG, Griffiths GS. Periodontal ultrasonography. J Clin Periodontol. 2003;30(10):849-54. https://doi.org/10.1034/j.1600-051x.2003. 00380.x.

51. Tyndall DA, Price JB, Tetradis S, Ganz SD, Hildebolt C, Scarfe WC, et al. Position statement of the American Academy of Oral and Maxillofacial Radiology on selection criteria for the use of radiology in dental implantology with emphasis on cone beam computed tomography. Oral Surg Oral Med Oral Pathol Oral Radiol. 2012;113(6):817-26. https://doi.org/1 0.1016/j.000o.2012.03.005. 
52. Vera C, De Kok IJ, Reinhold D, Limpiphipatanakorn P, Yap AK, Tyndall D, et al. Evaluation of buccal alveolar bone dimension of maxillary anterior and premolar teeth: A cone beam computed tomography investigation. Int J Oral Maxillofac Implants. 2012;27(6):1514-9 PMID:23189304.

53. Vollborn T, Habor D, Pekam FC, Heger S, Marotti J, Reich S, et al. Soft tissuepreserving computer-aided impression: a novel concept using ultrasonic 3D-scanning. Int J Comput Dent. 2014;17(4):277-96 PMID: 25643460.

54. Walter C, Schmidt JC, Dula K, Sculean A. Cone beam computed tomography $(\mathrm{CBCT})$ for diagnosis and treatment planning in periodontology: a systematic review. Quintessence Int. 2016;47(1):25-37. https://doi.org/10.3290/j.qi.a34724.

\section{Publisher's Note}

Springer Nature remains neutral with regard to jurisdictional claims in published maps and institutional affiliations.

\section{Submit your manuscript to a SpringerOpen ${ }^{\circ}$ journal and benefit from:}

- Convenient online submission

Rigorous peer review

- Open access: articles freely available online

- High visibility within the field

- Retaining the copyright to your article 